Article

\title{
Jews and Muslims in Dubai, Berlin, and Warsaw: Interactions, Peacebuilding Initiatives, and Improbable Encounters
}

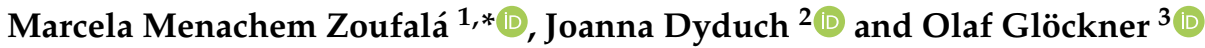 \\ 1 Centre for the Study of the Holocaust and Jewish Literature, Faculty of Arts, Charles University, \\ 11638 Prague, Czech Republic \\ 2 Institute of the Middle and Far East, Jagiellonian University, 30-063 Krakow, Poland; joanna.dyduch@uj.edu.pl \\ 3 Moses Mendelssohn Centre for European Jewish Studies, University of Potsdam, 14467 Potsdam, Germany; \\ ogloeckner@gmx.de \\ * Correspondence: marcela.zoufala@ff.cuni.cz or marcela.zoufala@gmail.com
}

Citation: Menachem Zoufalá, Marcela, Joanna Dyduch, and Olaf Glöckner. 2022. Jews and Muslims in Dubai, Berlin, and Warsaw: Interactions, Peacebuilding Initiatives, and Improbable Encounters. Religions 13: 13. https://doi.org/10.3390/rel13010013

Academic Editor: Gunther Jikeli

Received: 8 September 2021

Accepted: 11 December 2021

Published: 24 December 2021

Publisher's Note: MDPI stays neutral with regard to jurisdictional claims in published maps and institutional affiliations.

Copyright: (C) 2021 by the authors. Licensee MDPI, Basel, Switzerland. This article is an open access article distributed under the terms and conditions of the Creative Commons Attribution (CC BY) license (https:// creativecommons.org/licenses/by/ $4.0 /)$.

\begin{abstract}
What is the nature of interactions between Jews and Muslims in contemporary Dubai, Berlin, and Warsaw? The purpose of the three presented case studies is to evaluate the state of affairs and identify newly emerging trends and patterns in the given trans-urban context. The methodology is based on qualitative anthropological research, emphasising an emic perspective that centralises respondents' own lived experiences and worldviews. The main research's findings made evident that interactions between Muslims and Jews in each examined location are, to various extents, acknowledged, and in some cases, also embody a formative part of public discourses. Perhaps the most visible manifestations of these relations are represented by the ambitious interfaith projects that were recently established in each geographical area in focus. The Abrahamic Family House (UEA), The House of One (GE), and The Community of Conscience (PL) reveal the aspirations of multi-faith religious leaders to overcome polarising dichotomies and search for common ground. One of the conclusive outcomes of the study is a somewhat diminishing impact of the Israeli-Palestinian conflict on the Jewish-Muslim relations; however, the extent differs in each destination in focus. Finally, an unpredicted observation can be made. A surfacing inclination towards embracing a joint Muslim-Jewish Middle Eastern identity was perceived.
\end{abstract}

Keywords: Jews and Muslims; Dubai; Berlin; Warsaw; multi-faith projects; The Abrahamic Family House; The House of One; The Community of Conscience; cultural hybridisation; Abraham Accords

\section{Introduction}

The article aims to reflect and elaborate on the increasingly visible phenomenon of newly articulated relationships between Jews and Muslims in different geographical and socio-cultural contexts.

In search of a deeper understanding of the current status quo's roots, as well as trends and potential developments, this paper is dedicated to theoretical and empirical research on the relevance of the interrelated Jewish-Muslim experience to the multicultural global neighbourhood.

In his Philosophy of Mind, Hegel conceptualise the "Other" as a constitutive part of one's self-consciousness (Hegel 2007). Representations of the Jew and the Muslim embody a primary archetype of otherness inscribed in the shared collective imagination. As such, they personify figures crucial for mainly Western distinction and self-understanding (Jansen 2020; Renton and Gidley 2017; Pew Research Center 2019).

Stereotypically, in current mainstream discourses, Jews and Muslims are mostly depicted from the standpoint of mutual animosity as belligerents in an antagonistic entanglement. However, some of the recent ethnographies focusing on urban areas suggest that Jewish-Muslim relations can be complex and ambivalent, not necessarily inherently hostile or conflictual (Everett and Gidley 2018, pp. 173-96; Atshan and Galor 2020). 
The present paper is dedicated to mapping the mental landscape and imaginative forces exhibited by diverse individuals and communities within their pertinent intertwined cultural, religious, and economic backgrounds. Notably, it intends to expand the insights into various alternative worldviews (Weltanschauungen) as well as master/small narratives employed by interrelated Jewish and Muslim populations. It also seeks to uncover the said populations' resources, as well as the obstacles that hinder the construction of transcultural alliances, networks, and civil societies, primarily in metropolitan areas.

Both Europe and the Middle East have recently witnessed a trend towards reinforcing ethno-religious and ethno-nationalist identities. It correlates with the growth of populism, nativism, defensive nationalism, and extreme-right wing rhetoric-not only at the margins of the social, political, and media spectrum, but also in the mainstream conversations. When one thinks of other trends that carry transnational repercussions, political Islam, Islamism, and Muslim Antisemitism should be included as well.

At the same time, there has been an increasing number of independent initiatives and platforms dedicated to the interfaith and intercultural dialogues that seek to overcome the polarising rhetoric and alienation among diverse populations.

Two principal approaches can be observed in this sphere. In the top-down approach, the initiative originates from religious, cultural, and political leaderships. The bottom-up pattern emphasises people-to-people relations, which transpire in everyday encounters, grassroots movements, and community-building alliances. Both approaches, however, follow a shared vision of conviviality, togetherness, as well as mutual support in the fight against racism and xenophobia (in the case of the two populations under scrutiny here: Antisemitism and Islamophobia).

An unexpected breakthrough in trilateral interfaith relations recently happened in more or less similar ways in Berlin and Dubai. European and Middle Eastern metropolises host unifying multi-faith complexes, where each of the three monotheistic religions is represented. The House of One and the Abrahamic Family House both include a synagogue, a church, and a mosque. Multi-denominational houses of worship are extraordinary in their impressive design plans; yet, they are not entirely uncommon, as analogous facilities are being created in many, primarily Western, capitals. Along the same vein, an interfaith group, The Community of Conscience, has been recently initiated in Poland by a group of community leaders ${ }^{1}$.

In order to study the theme of this paper in various geographical and socio-cultural contexts and gain as broad a picture as possible, three cities, in which both populations in focus are represented, were selected. The first one is the Middle Eastern metropolis of Dubai, in which Jewish-Muslim interactions have only become publicly visible and encouraged since last year. The other two are Central-Eastern European cities: a cosmopolitan "Mecca", Berlin, and a relatively ethnically homogeneous capital, Warsaw. By observing how the two groups in focus cooperate (be it successfully or not) in their niches, we have gained a better understanding of the dynamics of their participation in social and political life in each of the three countries.

\section{Theoretical Framework}

We have decided to examine Jewish-Muslim relations within the settings of cities, rather than entire countries. As a consequence of globalisation, metropolises across different states often share more common traits with each other than with the more remote areas of their respective countries. Traditionally, capital cities were seen as an essence of the nation or its dominant ethnicity. However, their image has been transformed-they reflect the microcosm of a diversified society rather than a national or uni-ethnic environment (Leerssen 2018). It is needless to point out that the mere existence of cities has always constituted a challenge to the long term raison d'être of the homogeneous nation state. Complex urban spaces, in a similar manner, mirror the multi-ethnicity, eclecticism, re-tribalisation of society, cultural hybridisation, and other phenomena related to "the compression of the world and the intensification of the consciousness of the world as a whole", as globalisation 
was originally described (Robertson 1992). Along the same lines, "the post-modern city is a geographical celebration of difference that moves sites once conceived of as 'marginal' to the centre of discussion and analysis" (Gallagher et al. 2009). The above-mentioned common patterns enable a "trans-urban" comparative perspective, focused on the critical aspects of the life of diverse ethnic groups and their shared existence.

\section{Main Research Questions}

How do the examined groups perceive themselves and how do they view the world/city surrounding them? How do they position themselves in their respective environments? Do they experience a sense of belonging (sharing common fate) on the national, transnational, global, local, or trans-local level? Do they feel responsible for the well-being of their own community and/or members of other groups, or even the local/global majority society? How do Muslims and Jews perceive each other and their roles within society? Are their relations in Europe and the Middle East of a remarkably distinct nature and intensity? To what extent do religious commonalities and differences affect the JewishMuslim encounters in both regions, and to what extent are those encounters driven by the urban milieus of Dubai, Berlin, and Warsaw? ${ }^{2}$

\section{Methodology}

The article presents three case studies of three different locations ${ }^{3}$. The methodology is based on qualitative anthropological research with an emphasis on the emic perspective that centralises respondents' own lived experience and world-views. The main methods applied during the fieldwork were: participant observation, in-depth interviews, follow-up socio-cultural analysis of respondents' accounts, and a review of scholarly and media sources, according to an innovative method of Narrative Ethnography (Gubrium and Holstein 2009, pp. 241-64).

Interviewees from Jewish and Muslim environments in Dubai, Berlin, and Warsaw were selected by exponential non-discriminative snowball sampling, in combination with purposive sampling ${ }^{4}$. Social desirability bias ${ }^{5}$ and sampling bias were taken into careful consideration and tackled. The well-known nature of snowball sampling is that it cannot be considered as a representative sample. Therefore, the number of interviews was limited by the data theoretical saturation ${ }^{6}$. The methodological reflexivity was consistently applied from the early stages until the finalisation of the research process. The highest priority was given to the respondents' safety and emotional security.

\section{5. "Cousins' Meetup" in the New Middle East: Muslim-Jewish Encounters in Dubai}

"In an Arab country ... a Jewish community ... a growing community ... free of Antisemitism ... the first growing community in the Middle East outside of Israel ... the other communities are either gone or really shrinking... and here is one just flourishing!" ${ }^{7}$

In these words of praise, interview partner ${ }^{8}$ number 1 described the prevalent ethos within the Jewish Kehila in the UAE. This high spirit and encouraging self-perception were the most remarkable and repetitive patterns among all our Jewish interviewees' accounts in Dubai.

\subsection{Jews in Dubai: From Inconspicuousness to High Public Visibility}

After the UAE's Ministry of Tolerance officially recognised the local Jewish population in February 2019, the Jewish community stepped out of the shadows by giving interviews to the international media. Their "public visibility" (Ayoub 2016, p. 23) heralded, in a certain way, the establishment of diplomatic relations between the UAE and Israel in August 2020. The highest estimations of Jewish presence in all 7 Emirates reach $3000^{9}$ people. However, not all of them participate in the communal life. The community that consists of members from all around the world publicly celebrates Jewish holidays and virtually announces its support towards the UAE authorities on the communal website and Twitter account. At the moment, Dubai has a religious school, a Jewish Community Centre (JCC), and two 
functioning synagogues. The third, supposedly most extravagant shul ${ }^{10}$ in the world, is in the making as part of The Abrahamic Family House, an interfaith complex in Abu Dhabi that will include a church, a mosque, and a synagogue. Contrarily to Berlin, this project stands for the top-down approach. Obviously, in this instance, Jews represent a small minority among Emiratis and other UAE expatriates. ${ }^{11}$

Dubai is the second largest and the most populous emirate, with 3.43 million inhabitants as of 2021. Emirati citizens represent a minority outnumbered by the expatriate population in this cosmopolitan and globally renowned commercial hub. ${ }^{12}$

\subsection{Research Background}

The idea of carrying out research in Dubai became highly relevant in May 2020, when the local Jewish community opened the above-mentioned Twitter account and entered the virtual world as the "Jewish Community of the UAE", attracting worldwide attention. However, the clearer contours of the research emerged only after the signing of The Abraham Accords on 13 August 2020. Observing, collecting, and analysing online sources to prepare an anthropological fieldwork trip to Dubai took more than nine months, with the process delayed mainly by travel restrictions caused by COVID-19. The fieldwork on-site was eventually performed during the last week of May and the beginning of June 2021, and included preparatory communication, proper interviews, shorter talks with informants, and participant observation of the community events (Bar Mitzva and Shabbat dinner). The interviews were held mainly face-to-face in Dubai, both in public places (community events, cafes, and shopping malls) and in interview partners' private settings. Some of the interviews were conducted via Zoom after the return from Dubai, and one interview took place in person in Tel Aviv in July.

Altogether, the fieldwork led to eight in-depth interviews with six Jewish and two Muslim partners, as well as several shorter talks with five informants (some of them foreign workers living long term in Dubai). The Jewish interview partners originally came to Dubai from very diverse locations, such as Europe, the U.S., the Middle East, or South Africa. Not all of them spoke Hebrew. Hence, English was the main conversation language, with occasional Hebrew and Arabic vocabulary. Muslim interview partners were Emirati citizens and here, also, English proved to be a successful communication tool.

It should be noted that one of the Emirati interview partners studies Hebrew ${ }^{13}$ online in an Ulpan based in Israel, and both Emiratis showed high enthusiasm for Jewish-Israeli education and cultural heritage. One of them was approached during a Shabbat diner that he attended with his Jewish friends. Both of them are male with higher education degrees (one in social science, the other in engineering), and both are entrepreneurs. Among the Jewish interview partners (five males and one female), several entrepreneurs were to be found as well, together with rabbis and an IT specialist; five of them completed higher education degrees. The age of the Muslim and Jewish interview partners spans between 29 and 72 years old. ${ }^{14}$

Several interview partners were selected in advance to represent the plurality of voices and opinions. The rest was determined through the above-mentioned technique of snowball sampling, once the first interview had been held. However, approaching some of the interview partners and scheduling the proper appointments turned out to be more challenging than expected. One of the reasons was a certain exhaustion among the community members due to the media's unrelenting interest since the signing of the Abraham Accords. This sharp spotlight that was described by a few different interview partners created media fatigue.

Finally, due to the researcher's personal connections, the first, crucial interview was successfully held on private premises, after an informal encounter during a public Shabbat dinner. Other interviews were to follow. However, some of the interview partners agreed to have a conversation only after the repeated reassurance that accounts are not intended to be medialised and would purely serve research purposes. In contrast, other interview partners welcomed the opportunity to discuss their views and opinions. 
One of the peculiar and somewhat unpredictable aspects of the field trip was its timing, which added even more pertinence to the research to be conducted. The field trip started on 26 May, five days after the first serious escalation of the Israeli-Palestinian conflict since the signing of the Abraham Accords. The escalation concluded in a ceasefire between Israel and Hamas after 11 days of fighting, on 21 May.

Although these developments were obviously neither planned nor expected, the decision was made to carry on and adjust the research to the circumstances. Therefore, the plan for the interview was modified to include more questions regarding the feeling of safety as well as any latent signals of hostility, or even open Antisemitism, towards the Jewish community members in times of crisis.

However, the interview partners with whom we had a chance to discuss this sensitive issue agreed unanimously that they had never experienced any verbal or physical Antisemitic threat in Dubai, neither in general nor in relation to the recent escalation. Some of them even stated the opposite, describing support coming privately from their local social circles. Two of the interview partners mentioned that they were directly approached by the police to confirm they felt safe during the May escalation. One Muslim interview partner brought to our attention a related incident, when a foreign worker originally from an Asian Muslim country had spread Antisemitic comments in a partially public online group. Subsequently, he was deported from the UAE.

In general, the Israeli-Palestinian conflict, particularly the consequences of the recent escalation, was not perceived as having a significant influence on the mutual relations between the hosting Emirati society and the Jewish minority. A certain indifference to the long-standing conflict seems to be a part of a broader trend, illustrated by the circulation of the hashtag "Palestine is not my cause" that appeared on Twitter in May. Nevertheless, two Jewish interview partners criticised the role Israel played in the latest escalation and expressed concerns regarding possible repercussions from creating a hostile environment.

In this context, it should be noted that any community events (not even large gatherings) require a visible presence of security forces or a frame metal detector. At the same time, as we were told by interview partner number 2, "thousands of undercover police"15 are protecting the streets.

Interview partner number 3 also described a sense of insecurity upon their arrival to the UAE almost a decade ago: "Many people warned us not to come here-they thought we were insane. (...) In the beginning, we were not sure what is allowed or not, and we even used code words to communicate with other Jewish families while setting up the festivities. For example, M.O.T. (Members of the Tribe) stood for Jews or RH for Rosh Hashana. After a while, we understood that nobody really cares what we are doing. (...) The general philosophy is whatever you need to do, do it privately and keep the rules. This was the ethos of the UAE built on Sheikh Zayed's vision". ${ }^{16}$

\subsection{Jewish Community Division}

To complete the picture, there was a third underlying reason for why some of the interview partners were reluctant to put their thoughts on record. It had to do with a particular situation within the Jewish community or, to be more accurate, communities. Currently, the UAE is supposed to have three permanent rabbis: Chief Rabbi Yehuda Sarna and Senior Rabbi Elie Abadie, who run The Jewish Council of the Emirates (JCE), and in parallel a Chabad rabbi Levi Duchman leading the Jewish Community Center of UAE (JCC). In this context of two parallel structures, some of the interview partners and informants made a somewhat predictable suggestion: one of the bones of contention is the decision on who will represent the Jewish community in the Abrahamic Family House- the choice to be made by the Emirati authorities.

The description of the current situation can be considered as less relevant to the local Muslim-Jewish relations. Nevertheless, the rich internal Jewish debate, held partly in public, convincingly proves that members of the Jewish communities feel free to speak their minds outside of the communal spaces. There is no urge to create a unified image for 
the sake of the majority of society's recognition. This authentic and confident presentation of the quarrels among the UAE Jews testifies in favour of their positive self-perception in that particular environment.

\subsection{We Remember}

One of the significant events of the field trip was a visit to the Crossroads of Civilisations Museum that opened the Gulf's first exhibition dedicated to the victims of the Holocaust, just one week before the on-site research took place. The exhibition, entitled "We Remember", which should become permanent, includes a section introducing Muslims who saved Jewish lives during the Holocaust. During a conversation with an Emirati founder and curator of the whole project, we discussed the local population's readiness to acknowledge also the topic of anti-Jewish violence, specifically Middle Eastern pogroms, such as Farhud. Considering the sensitivity of the issue, the expectation of receiving a positive answer was rather low. Surprisingly, the exhibition owner asserted he had already been asked the same question by British visitors. In response, he offered them a space to establish such an exhibition, provided they could supply relevant documentation. "We cannot live in denial," he concluded.

\subsection{Discussing Uncomfortable Questions}

Undoubtedly, the leadership of the UAE is currently not aspiring to maintain higher standards in the area of human rights or to apply democratic principles. This is why it is often criticised. The efforts to strengthen the value of tolerance so as to intensify intercultural exchange and establish interfaith platforms are sometimes labelled as deliberate "faithwashing", performed for the international community's eyes, or as business incentives for foreign investors. ${ }^{17}$

The image of the UAE, and especially of Dubai, as a liberal cosmopolitan hub in an almost Western style is purposefully maintained and cultivated. To further this narrative, the situation of the Jewish minority is used somewhat instrumentally as an example, although it must be said that its members are often willing to publicly demonstrate their well-being and show how, for instance, they can wear kippa in public places without fear. At this point, the image desired by the Emirati authorities becomes a reality.

Wearing religious symbols has been an unattainable goal for Jews in Europe over the last decade. Jewish religious authorities in major European cities periodically warn their followers to remain discreet.

The situation in France is probably the starkest example: it has gradually worsened throughout the last two decades, culminating recently in the highly controversial and disputable ruling in a medialised case of the Antisemitic murder of a 65-years old Jewish kindergarten teacher, Sarah Halimi. ${ }^{18}$ The ruling was issued by France's highest court of appeal, the Cour de Cassation, in April 2021 (Euronews 2021). Even though Halimi's case has been one of the most publicised and commented on incidents of this kind (also due to its cruelty and the inability of the French judicial system to act properly), it is certainly not unique. Many studies have convincingly proven the increase in notably violent, partly Muslim Antisemitism in France (Jikeli 2020; Lev Ari 2022).

The ruling set a dangerous precedens, claiming that Europe is not only unable to protect its minorities, but also unwilling to publicly condemn violence against them and to label it as a punishable hate crime. It would be, however, an unacceptable relativisation and incorrect reasoning (in the style of $t u$ quoque) to justify the violation of human rights in the UAE by referring to a politically motivated lack of judgment in the EU-in other words, "two wrongs don't make a right". Nevertheless, it can be determined that the desired image of the EU as a normative power and globally accepted moral example can soon deteriorate further if it is not cherished and safeguarded, with high priority as an exceptional value. 


\subsection{Abrahamic Cousins}

In conclusion, a final and rather surprising observation can be made. There is a surfacing inclination (that, at this point, is barely nascent, and more of a potential development than a clear reality) towards embracing a new Middle Eastern identity that unifies Muslims and Jews. The discourse relies on the concept of Abrahamic cousins, or even "Arab brothers" (UIBC 2021) in the case of Mizrahi Jews. To illustrate the common ground of three religions, interview partner number 4 paraphrased the Qu'ran's Sura V.32: "Who saves one soul saves the whole of humanity". "The same as Judaism and Christianity got"19, he noted.

Apart from the ancient texts, quite recent tropes are being employed in the surfacing discourse; for example, "[Let's] make the Middle East great again", the expression with which the same interview partner summarised his enthusiastic speech by saying: "the light used to come from the Middle East, the Middle East and North Africa ... we were helping.. we were contributing to the world ... since we have a conflict, we are going down to drainage the whole Middle East ... in order for us to make the Middle East great again, we need to find a way how to work together ... if we have a conflict we all lose ... ", he warned.

There are also interesting reciprocal perceptions built on mutual authentic encounters, rather than staged events. Interview partner number 4 shared a quick humorous exchange: "At one international conference before the signing [of the Abrahamic accords], one of my Israeli friends asked me '[Name of the Emirati interview partner], you know, we are Israelis, we are very tough, very straightforward, are you guys [Emiratis] ready for us? Well, you guys are very straightforward but not transparent at all. We are very transparent but not straightforward, so we can complement each other, I replied.'”

This phenomenon that, ad hoc, could be called a "\#Cousins Meetup identity" 20 (see also Figure 1) attempts to consolidate itself by searching for its counter-image in the Western countries. As one respondent formulated it: "those that colonised our lands and betrayed us, by MacMahon's Letter and Balfour Declaration, us Muslims and Jews".

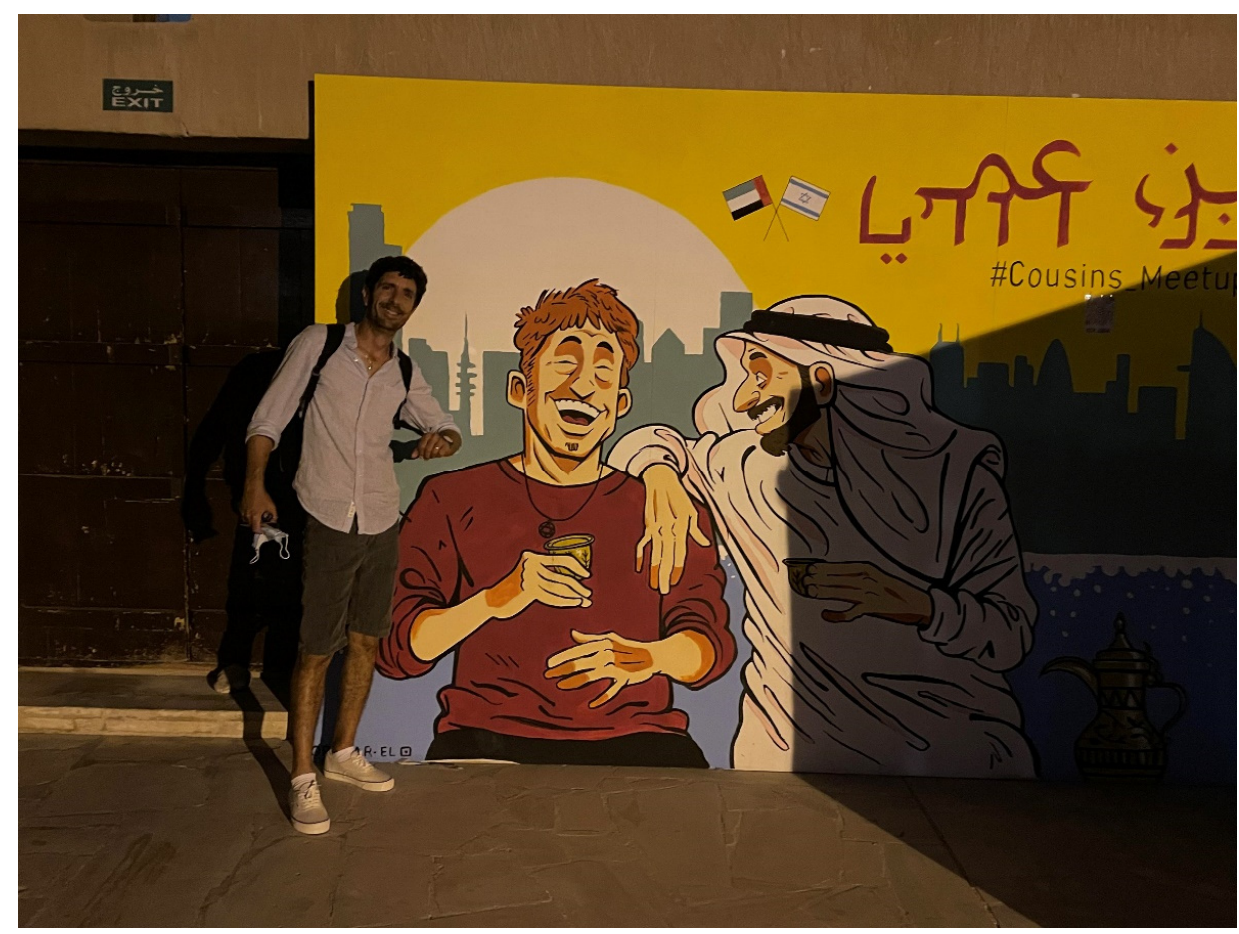

Figure 1. \#Cousins Meetup, The graffiti mural with the "Cousins" logo, made by Israeli artist Or Bar El, was dedicated at a ceremony at the Crossroads of Civilization Museum. Photo courtesy of Karmi Menachem, Dubai, May, 2021. 


\section{Berlin as a the European "Urban Laboratory" of Jewish-Muslim Encounters}

Berlin—the former "Aryan" Nazi Capital—appears today as a place that surpasses intercultural and political tolerance and of an "ultra-liberal" atmosphere. This is visible, for example, in a broad cultural and socio-cultural scene, where multicultural encounter is not only tolerated but explicitly desired. In this respect, Berlin contrasts even with many other German cities, but has become a symbol for a "new Germany", which is totally different from the authoritarian, nationalist, and militarist state it was 100 and 80 years ago. This new constellation opens a wide range of opportunities for intercultural and interfaith encounters, even more so since the German reunification and the influx of new immigrant groups, which include many people who understand (cultural) integration as a process of mutual learning and enrichment. Jews and Muslims are part of that process and experience.

Since the 1960s, Berlin's population has become more and more heterogeneous and multicultural due to various factors and developments. Tens of thousands of Turkish migrant workers came here (also to other German cities), joining political refugees from Eastern Europe, war refugees, and politically oppressed people from the Middle East (for example Lebanon, Afghanistan, and Iran).

As of June 2019, Berlin was home to 150,705 people (or 4.0 percent of its population ${ }^{21}$ ) with an Arab migrant background. This is less than the estimated Turkish population of Berlin (ca. 200,000), but more or less the same number as that of the Russian-speaking, former Soviet people in Berlin, estimated to be around 142,091. ${ }^{22}$ Many Arabs live in densely populated areas, for instance in Neukölln, Kreuzberg, and Wedding. Since the 1960s, many Turks have also settled there. As a consequence, Muslim Berliners have built their own mosques, while the Turkish communities are often led by Imams sent and paid by the Turkish Ministry of Religion.

Compared to the above-mentioned groups, nowadays, Jews are a rather small ethnocultural minority. Prior to 1933, Berlin had around 160,000 people registered as Jews. ${ }^{23}$ After the end of World War II, only very few synagogues could reopen in the city and the number of Jews returning here to stay remained low. Thus, the number of registered Jewish community members in Berlin has since not exceeded ca. 11,000 people.

In German politics, relations with the small post-War Jewish community have retained a certain special status, expressed primarily in infrastructural support. The Muslim population has become a more important topic since 2015, when more than one million refugees from Middle Eastern countries found shelter in Germany. Parts of the media also raised the question of the extent to which this significant influx could also endanger the security of the local Jewish communities. ${ }^{24}$ Even before that, a few religious and spiritual leaders from Jewish and Muslim institutions and organisations in Berlin had initiated platforms and projects of a Jewish-Muslim dialogue and Jewish-Muslim-Christian trialogue, in an attempt to create broader channels of interfaith communication and address mutual reservations. Such activists are not necessarily backed by the majorities of their Jewish, Muslim, or Christian peers.

\subsection{The House of One-A Laboratory for Jewish-Christian-Muslim Encounters}

One fairly new and innovative project of the aforementioned interfaith dialogue is the so-called "House of One" in downtown Berlin. Jews, Christians, and Muslims are planning to build a house of worship-one that brings a synagogue, a church, and a mosque under one roof. The house shall also be open to the public and offer ample space for meetings. Imam Osman Örs, one of the Muslim protagonists in the team, explained the basic principles behind this joint, interreligious project:

"We are interested to invite all kinds of religious groups and movements who are not questioning the basic principles of our Charta —and this includes: no religious proselytisation and no politicisation. We are of course, also open to inviting other groups of contemporary Islam, Judaism, Christianity which are not yet represented in the House of One-as for example, also Shi'ites ( . . . ) There are greater visions beyond. The project, the house, is big, but the idea is much bigger" ${ }^{25}$ 
One of the female Muslim activists connected with the House of One, the theologian Kübra Dalkilic, states: "We need to internalise that we have one and the same God in common. It should be possible that we realise us as believers with different contents of faith, but as human beings who can treat each other very fairly, and that we can operate a lot of positive things in this city. We don't know how the House of One-when the building is completed and religious life starts inside-will be accepted in the public then, but I am rather optimistic". ${ }^{26}$

The interview partners we have met in Berlin-three from the Jewish and four from the Muslim side-offered similar, but also individual, motivations to engage in the Abrahamitic trialogue, or even in specific Muslim-Jewish projects. Seda Kolac, born as the third generation in a Turkish-German immigrant family, wears a headscarf for religious and traditional reasons, similarly to Kübra. She has recently started working in an intercultural project entitled "Schalom Aleikum". The initiative is run by the Central Council of Jews in Germany. It seeks to decrease mutual prejudice and reservations between Jews and Muslims through direct encounters. The project has quickly gained ground in four other German cities beyond Berlin. Joint forums are organised to bring together Jews and Muslims who share interests and professional or personal experiences-for example, start-up entrepreneurs, scholars, doctors, gastronomists, artists, and representatives from the respective LGBT scenes.

\subsection{Muslim-Jewish Encounters in Berlin's Public Sphere-Right at the Beginning}

Seda emphasised that the work performed for the "Schalom Aleikum" project has allowed her to explore and gain new insights into the Jewish world. She also noted the rising number of creative projects for which Muslims and Jews closely cooperated. "Though, this does not automatically mean that the mutual interest between Muslims and Jews is growing". ${ }^{27}$ This is clearly different from the situation in London, a place she has also been to several times. "Joint projects of Muslims and Jews are considered quite regular there and are not seen as something exotic. Here in Berlin, it's still something unique when a Muslim and a Jews enter the same stage-and this shows how far we are still from normalcy". ${ }^{28}$

Kübra Dalkilic had first studied Islamic Cultural Studies, but then realised "that I am not only studying this by interest, but that I am living this". She also realised that she wanted to be seen as a religious, young Muslim woman who was, at the same time, very much affiliated with the German society and with other religious denominations as well. "When I moved to Berlin, I was very much delighted by this idea of a House of One", Kübra says, "and this especially as a woman who meets other religious women in the same project, sharing common values, but also good and bad times". ${ }^{29}$

Ruth Fischer, the daughter of an Israeli-Jewish mother and a German father, who grew up in Berlin, Charlottenburg, has over a decade of experience in intercultural work with teenagers. She confirmed the notion that religious differences between Jews and Muslims were clear to define, but were also not at all the reason for behaving in a distant manner. Ruth also saw a huge potential for cultural (and religious) resources on both sides, waiting to be used to increase the number of encounters and the degree of mutual understanding. "It might sound banal, but maybe a comparison from the world of sports can help: Fans of Borussia Dortmund and Bayern Munich are connected by their love to football, but divided by loyalty to their respective clubs. But nobody would think about to problematise this constellation. This is just the world of football, everybody feels well inside. And at the end they have more in common than the things that separate them". When asked about her frequent contact with Muslims, Ruth answered ironically: "To grow up in Berlin, and to have no contact to Muslims, is almost impossible". ${ }^{30}$

A different story is that of Susanne Krause-Hinrichs, a Jewish lawyer, who has run the F.C. Flick Foundation in Potsdam (the capital of Berlin's neighbour state, Brandenburg) for almost 10 years. The foundation primarily seeks to combat racism, violence, and xenophobia, but is also committed to fighting Antisemitism and running intercultural as well as international workshops and projects. On the one hand, Susanne cooperates with 
similar Muslim initiatives in Berlin. On the other hand, she (and her foundation) has been very engaged in the local help for refugees from North Africa and the Middle East who came to Germany in greater numbers, from 2015 onwards. Susanne detected commonalities between Jews and Muslims, "primarily by their reference to the Middle East, what makes a lot of ethno-cultural bonds. And not to forget: Both of our groups have faced a lot of experiences with discrimination". ${ }^{31}$ Susanne also thinks that the common living space (in Berlin and Brandenburg) would be a good ground for becoming closer, and she denies there are irreconcilable religious or cultural differences between Jews and Muslims.

Kadir Sanci, an Imam of the Gülen movement committed to the House of One project in Berlin and a University lecturer for Science of Religion at Potsdam University, confirms: "We have similarities in our story of suffering and in the social challenges that we have to face. At the same time, there are very great similarities in our respective understanding of religion. For example, Muslims today are experiencing a vilification in the arts and by means of caricatures. Such experiences by Jews, among other things, have regrettably led to the Shoah in history". 32

Interestingly, none of the interview partners, neither on the Jewish nor on the Muslim side, concluded that the unsolved Israeli-Palestinian conflict could damage their close relations with "the other side" so as to make it unsustainable. Seda Kolac confirmed that "in such situations of escalation, it becomes more difficult to mobilise additional people for the interfaith and intercultural work". 33 Others talked about a certain reservation to raise the issue. However, some of the protagonists did also emphasise that they were not willing to be divided by polarising activists (on both sides) or by biased media reporting on the conflict. On the contrary, both are convinced that there is a specific potential in both religions-Judaism and Islam-that could be employed to diminish such escalating conflicts between (Jewish) Israelis and Palestinians.

Apart from religious proponents of more substantial encounters between Jews and Muslims (and, hopefully, between Israelis and Arabs in Berlin), there are also secular actors pursuing the same direction.

\subsection{There Are Opportunities to Burst This Vicious Circle}

One of the most unconventional projects, now run mostly by young Israelis, is "Shalom Rollberg" in Berlin-Neukölln. "Can't Muslim and Jewish Berliners learn, work and have fun together?", asks the project manager on the project website and affirms: "Things are completely different at Shalom Rollberg! Interreligious and intercultural encounters take place here every day". 34 "Shalom Rollberg" is intended as a volunteering platform for Jewish Berliners to fight Antisemitism and Islamophobia and to promote education for mainly Muslim children and young people in Neukölln. Its activists encourage encounters in everyday life and try to break down prejudices and mutual fears through contact. Kids, primarily from Muslim families, attend English courses, Kung-Fu, yoga, or just play creative group games.

A large number of the inhabitants and families in the Rollberg neighbourhood have a low income and limited opportunities for improving their situation. Prejudice against other groups (including Jews) is widespread here. "We are just here to provide the kids of the area some leisure time activities they usually don't have. Our volunteers are Jews, mainly Israeli Jews, and the kids know this. The families let them come here, sometimes they bring some cake or show other gestures of gratitude", says Yonatan Weizman, the current leader of the project. ${ }^{35}$ Weizman considers himself as completely secular and emphasises: "We live in a world of violence and hatred, but there are opportunities to burst this vicious circle. Each of us can do something, and this is our attempt". ${ }^{36}$

Thus, apart from the Abrahamic "trialogue" initiatives, there is an increasing number of projects that specifically target the Muslim-Jewish exchange. Such efforts are undertaken by both sides - a fact that might indicate that the Jewish-Muslim relations in Berlin are, in fact, improving. In recent years, the Salaam-Schalom initiative in Berlin Neukölln, founded at the end of 2013 by young Jews and Muslims, also gained a lot of attention. 
Salaam-Schalom stands for peaceful solidarity, religious exchange, but, explicitly, also for the joint fight against Antisemitism and Islamophobia. ${ }^{37}$

However, the protagonists we have interviewed tried to remain realistic and were not sure about how great of a synergy effect their initiatives could generate among a wider population. Interestingly, more than a few interview partners-irrespective of their level of religiosity - detected a lot of commonalities in the daily religious practices of Islam and Judaism (or, at least, more than between Judaism and Christianity). Our interview partners did not see their cooperative work seriously threatened by escalations of the unresolved Israeli-Palestinian conflict in the Middle East. Some of them even felt compelled to demonstrate that Jews and Muslims are able to live a peaceful life together in the heart of Europe.

\section{Warsaw's Multiculturalism: Coexisting without a Relationship}

Throughout the centuries, Poland's capital, Warsaw, known for its dynamic and sometimes dramatic history, has been a city of many nations and cultures. Ever since the Middle Ages, due to its geopolitical location, Warsaw was considered the Central-Eastern European melting pot. The contemporary character and a specific nature of today's Warsaw stems from several factors, the most significant of which is the fact the city was almost completely destroyed during World War II. In 1938, the population of the Polish capital stood at 1,295,000. In January 1945, only 162,000 people lived in Warsaw, although the number quickly grew in the following months (GUS 2018). According to a census of Warsaw held on 15 May 1945, the population increased to 378,000 inhabitants (CzerwińskaJędrusiak 2009, pp. 7-8). Undeniably, the city suffered from discontinuity, which has had tremendous social and cultural consequences. These events still resonate in the lives of contemporary Warsaw's citizens, in the 21st century. The city is far more diverse in terms of ethnical, religious, and cultural influences than the rest of the country, which is quite homogenous.

\subsection{Research Background}

The study presented in this article is based primarily on empirical research, including in-depth unstructured interviews with representatives of Jewish and Muslim communities. Nine interviews were carried out in the summer of 2021 (June, July, and August). The main principle in the selection of the interlocutors was to capture the diverse nature of the studied groups. As for the Jewish community, there were three interviews with community members (both female and male), actively participating in the congregation life and engaged in the public affairs within the urban space. Meanwhile, Muslims in Warsaw are, to a great extent, a community of migrants with very different backgrounds, including the recently arrived political asylum seekers as well as Arab Muslims who came to Poland to study in the 1970s and 1980s and have lived there since.

In the case of both minorities, we sought to reach out to community leaders as well as regular members, representatives of younger and older generations. We intended to keep our investigation gender-balanced. Hence, among Warsaw's interview partners, we had four female and five male respondents.

As a result, we collected findings which created an interesting multidimensional picture of contemporary Warsaw's urban space, for which several trajectories of religious, cultural, and political processes have been cross-cutting, contributing to not necessarily obvious dynamics. In addition to an in-depth analysis of the field work outcomes, an extensive desk-research has been conducted in order to contextualise and better understand interview partners' testimonies and reflections. Thus, the study has been informed by an extensive analysis of secondary sources, which included: existing literature (e.g.,: Krajewski 2005; Górak-Sosnowska 2011; Switat 2017; Bobako 2017; Narkowicz and Pẹdziwiatr 2017; Skowron-Nalborczyk 2016, 2020), expert reports, and contemporary media sources. 


\subsection{Jews in Warsaw}

Inter-war Poland (1918-1939) was the world's second biggest centre of Jewish life, with a vital and diverse Jewish Community, constituting 10\% of the country's total population. In 1918, Jews constituted $42.2 \%$ of the total population of Warsaw. After World War II, the Jewish community in the country shrank significantly. As noted by Lucjan Dobroszycki, altogether, about 250,000 Jews stayed in Poland for varying periods. Warsaw has remained the most important centre of Jewish life in the country. Nearly $13 \%$ of Polish Jews sought residence in the capital (in July 1945, there were 50,000 Jews in Warsaw), a higher proportion than the approximately $11 \%$ who had lived there before the war (Engel 2015, pp. 564-65). However, this number has been drastically reduced as a result of waves of emigration. There were four mass waves: 1945-46, 1949-50, 1956-57, and 1968-69 (Dobroszycki 1973), each with its specific causes and course, and each accompanied by Antisemitism and hostility from the post-war communist regime. As soon as 1949, the activity of Jewish organisations was being limited, as Zionist parties were banned. Other Jewish organisations were subjected to the strict control of state apparatus. From the beginning of the 1950s, state institutions, gradually, through propaganda campaigns, created a negative image of Israel and Antisemitism has been recognised by the communist leaders as a tool for political conflict—a fact which has had tragic consequences for Jewish life in Poland, particularly in Warsaw.

The 1990s was primarily a time of a great political, economic, but also socio-cultural transition, with a rebirth of Jewish life among one of many significant changes. As soon as 1993, the Union of Jewish Religious Communities in Poland was officially established and recognised by state authorities as a continuation of the Religious Union of the Mosaic Faith, established in 1946 (a legal successor of pre-war Jewish communities). However, as one of our interviewees admitted, in cultural and social terms, an important feature of the "contemporary Jewish community in Poland is its 'discontinuity" (Warsaw's interview partner number 3). This, in turn, is very much related to the most dramatic chapter of the history of Polish Jews: the Holocaust.

According to the last National Census of Population held in 2011, 7353 Polish citizens declared themselves as belonging to the Jewish minority. Out of that number, 2690 people lived in the Mazowieckie voivodeship (GOV.pl 2021) within its capital, Warsaw. As for Warsaw itself, a more precise estimation can be made by looking into the number of members of Jewish organisations active in Warsaw. The largest one of these is the Warsaw orthodox Jewish congregation with ca. 700 members. It is also the largest community in Poland (GUS 2019). However, Warsaw is a seat for other religious communities working under the roof of congregation (such as the progressive Etz Chaim community) or independently (e.g., the liberal Bait Warszawa established in 2009 and the Chabad Lubavitch community, which started its operations in Warsaw in 2005). There is also an important cultural, but not necessarily religious, centre of Jewish life: the Jewish Community Centre.

Therefore, it can be said that Jewish life in Warsaw is characterised by religious and cultural diversity - this is actually not unique, as it follows a typical trend for Jewish lives in other European metropolises. The divisions reflect the different approaches to religiosity but can also be seen as a form of development that often stems from disagreements on certain issues. Such was the case of Bait Warszawa, which split into Beit Śródmieście and Beit Konstancin (Warsaw's interview partner number 1). However, the Jewish life in Warsaw maintains its coherence: different groups coexist and interpenetrate each other. A good example, here, is the Jewish Lauder School (a primary and high school), attended by children from families with different religious backgrounds, both liberal and orthodox, as well as non-Jewish, Polish pupils (Warsaw's interview partner number 1).

On the one hand, the diversity within the Jewish community's life is seen as a manifestation of development. On the other hand, it is also linked to the issue of leadership. It seems, however, that there is some kind of generation gap in terms of leadership. The readiness of the younger generation to be more deeply involved in the development of community life remains an open question. Another variable, mentioned by our interlocu- 
tors, which can influence the scenarios for the future, is a gradual withdrawal of financial support from international Jewish organisations, such as the R. Lauder Foundation. It has been argued the Polish Jewish community "has grown up" already and, as a result of the reprivatisation of Jewish communal property, it has managed to accumulate the capital needed for further organisational development (Warsaw's interview partner number 2). As noted by a Jewish community activist and educator, "now is such an interesting moment that international Jewish organisations are withdrawing from Poland, withdrawing their financial support for us. And now we must learn to live without the subsidy flow that has been the driving force of development over the past 30 years. On the one hand, it's difficult, but on the other hand maybe it's time to live on our own account" (Warsaw's interview partner number 1).

\subsection{Muslims in Warsaw}

The Muslim community in Poland constitutes only 0.7 per cent of the entire population. Yet, still, it is very difficult to precisely indicate how many Muslims live in Poland's capital, Warsaw. According to various estimates and sources, up to 40,000 Muslims live in Poland and nearly one third of them are Warsaw inhabitants (for more details see: GUS 2019, pp. 251-62). Although the Muslim community in Poland can be considered as small, it is quite diverse. The autochthonic Polish Muslims, the Tatars, who have lived in Poland for 600 hundred years, are settled mostly in the Białystok region. The first significant nonTatar groups of Muslims arrived in Poland in the 1970s-these were mostly Arab students. Finally, it can be said that there is a third group, mostly refugees and asylum-seekers, which started to arrive in Poland over the past two decades. At first, they were Muslims from the Caucasus region (mostly Chechens) and, later, refugees from the Middle East. More recently, the city has been a destination for economic migrants (from Bangladesh, Indonesia, Pakistan, and, to a lesser extent, Turkey). It can be said that the Muslim community in Warsaw is a community of migrants. For many of them, Poland has not been the dream destination, as they intended to transit to other Western European countries, for instance Germany.

While Tatars gathered in the Muslim Religious Union are an almost non-existent community in Warsaw, the Muslim League ${ }^{38}$ that runs the Muslim Cultural Centre in Warsaw holds a dominant position. Their mosque, located in Warsaw's so-called Blue City, opened in 2015, is the largest progressively developing centre of Muslim community life.

Probably, the greatest challenge and disadvantage for Muslims living in Poland is a growing level of prejudice based on negative stereotypes. According to Adam Bodnar, Polish Ombudsman, Muslims suffer from acts of aggression, hate speech, and various kinds of discrimination. All this can be observed as the specific aftermath of the migration crisis, with its peak in 2015, and the following mainstream public narrative (Bertram et al. 2017). Moreover, in the most recent public opinion polls, Muslims are mostly negatively perceived by Poles (CBOS 2019). A vast majority of respondents claimed that Muslims living in Europe are unwilling to assimilate and adopt the customs and values of the majority $(66 \%)$, are intolerant $(63 \%)$, and, finally, generally accept the use of violence against followers of other religions (50\%). Interestingly enough, the image of Islam and Muslims in Poland is primarily based on media reports, and not respondents' own experiences (Bertram et al. 2017). When describing their struggle with Islamophobia, Polish Muslims referred to "how Jews were treated a hundred years ago", underlining that "now this is how Muslims are treated" (RPO 2016). As noted by one of the interviewed experts, saying "almost everything about Muslims" —including Islamophobic statements and opinions that "could never be said publicly about Jews" - is widely acceptable in the Polish society (Warsaw's interview partner number 7).

\subsection{Warsaw's Multicultural Global Neighbourhood}

While Warsaw naturally shares some characteristics with other metropolises, it definitely has its own character that very much results from the city's contemporary history. 
One aspect that drives social interactions is the fact that $49 \%$ of contemporary Warsaw's citizens were not born in the city (Wagner et al. 2016, p. 276). Therefore, a traditional social trajectory, resulting from the fact that people would have friends from their childhood or school period, very often is not the case in Warsaw. People live in bubbles, often working a lot and not interacting with others as frequently as if they were in their hometowns. Thus, for those who have settled in Warsaw at some point in their life, there is less of a "social fabric", without which it is more difficult to be connected and attached to the urban social substance.

Moreover, as concluded one of the interviewees, "the city is huge, spilled and badly designed in terms of communication ( ... ) and all this is not conducive to meetings, which are a precondition for maintaining and strengthening real relationships and social ties" (Warsaw's interview partner number 7). Of course, one should not forget about the devastating consequences of the COVID-19 pandemic, in this regard. This reflection has been elaborated further by another interview partner, who admitted that "in Warsaw, too much is going on, and because of that, a lot of things would not have a proper rank and importance, and many of initiatives would just 'fly away' without grabbing wider attention" (Warsaw's interview partner number 6).

In addition to that, our interlocutors perceived the Warsaw municipal authorities as rather passive or, sometimes, reactive when it concerned their relations with minorities. Recently, the municipality has become almost invisible when it comes to initiatives promoting intercultural dialogue. Perhaps this is because Warsaw, as a capital city with is metropolitan dynamics, is influenced by global themes and trends, rather than being focused on locality and its trajectories.

\subsection{Jews and Muslims in Warsaw-From Interactions to Relationship}

As observed by one of the interviewed experts, "interactions between Muslims and Jews in Warsaw are rather irregular, unsystematic and non-institutionalized" and they cannot be seen as well-established relationships. ${ }^{39}$

The above-mentioned interactions, happening on a personal level, refer to the community leaders rather than to regular individuals (Warsaw's interview partner number 8). As highlighted by one of the interlocutors, "people living within majority society would not show their religious affiliation", especially in a city like Warsaw, which is highly secularised when compared to the rest of the country (Warsaw's interview partner number 9).

Nevertheless, initiatives bringing together community leaders under joint actions, while still incidental, have a ground-breaking potential. One such undertaking is the visit from over 60 prominent Islamic scholars from 28 countries who, in 2020, on the initiative of the American Jewish Community, came to Poland. The Jewish-Islamic delegation first jointly visited the Auschwitz-Birkenau Memorial Site on 23 January, to later spend a day in Warsaw, where they were hosted by the local Jewish community celebrating an interfaith Sabbath dinner (AJC 2020).

It is worth noting that this unique event, although very limited in time and space, had a significant continuation. A year later, on 22 February 2021, The Community of ConscienceA Coalition of Mutual Respect was established. The Community is a group of twelve people ${ }^{40}$ coming from various religious communities and organisations (Muslim, Jews, and Christians). The people who created it represent only themselves, not the religious communities they belong to, but because each of them plays an important role in a given community, the initiative is of great importance. Its declared mission ${ }^{41}$ is to be a voice of solidarity expressing unity out of its concern for fundamental human and civil rights. As noted by the initiator and coordinator of the initiative, "it took some time to convince community leaders not only to meet somewhere but, more importantly, to speak out with one voice". He explained that "each of these communities struggles with so many different internal challenges and difficulties that engaging in something 'external' may remain at the end of the priority list. So, somehow there is a thinking, let's first organise ourselves and clean up what needs to be cleaned up within our community, and only then let's think 
of doing something 'outside' or in partnership with 'others' (Warsaw's interview partner number 2)". Nonetheless, the Muslim clergy's visit to Poland was a clear success and has contributed to building an atmosphere conducive to creating a genuine sense of community. The interest in the Muslim-Jewish dialogue has increased and it has been noticed that there is some space for development and a social demand for this kind of relationship. The resulting message has the potential to overcome differences and divisions.

At the same time, there is no doubt that the so-called regular community members are well aware of the existence of "other" minority groups. Moreover, Jews and Muslims in Warsaw constitute an important reference point for each other, at least discursively. Sometimes, they would symbolically support each other. In 2010, the municipal authorities of Warsaw decided to hand over a land plot in one of the districts, Ochota, to the Muslim League for the purpose of building a mosque. The move sparked protests, which the association of Polish Jews, B'nai B'rith Polin, found incomprehensible. Moreover, a group of Warsaw's Jewish activists issued an open letter published via electronic media supporting the Muslim community (Wyborcza.pl 2010). Sometimes, the two communities would exchange invitations to participate in public educational events. A good example of this is a debate organised by the Danube Institute for Dialogue ${ }^{42}$. The event entitled "Dialogue in Abrahamic Religions: Our Shared Responsibility", which took place on June 2021, saw ideas, such as brotherhood, respect, and tolerance, discussed by a member of Warsaw's Jewish Community-Konstanty Gebert, a catholic priest, Grzegorz Michalczyk, and Professor Aldona Piwko, Islamic studies expert from the Vistula (Warsaw's interview partner number 6).

On more than one occasion, Muslims with a refugee background had experiences of receiving support or help from Polish NGOs, mostly those visible and active in Warsaw. Our empirical study revealed that this exact context has turned into an opportunity for JewishMuslim interactions. One of our Muslim respondents-a female refugee from Chechnyasaid that the first Jewish person she had ever met was a woman who volunteered to work with refugees in a closed detention centre, in Kętrzyn. While recollecting painful memories from that extremely difficult period of her family life, she underlined the great help she received from the volunteers, in terms of preparing necessary documentation, but also financial support and, most importantly, friendship (Warsaw's interview partner number 5).

This theme, as if as a mirror image, appears in another conversation held for the purpose of this study. A younger generation Jewish respondent, while speaking about family history and heritage, admitted: "I grew up in a family that has been socially involved for generations ( . . ) my mother for almost 20 years ran an office for refugees in the Polish Humanitarian Action. She died 10 years ago, but when she was alive, she was probably the most important person when it comes to helping refugees in Poland, helping in a legal, material and emotional sense (... ) Today her work is continued by my older sister" (Warsaw's interview partner number 5).

In conclusion, it can be said that the coexistence of the two religious minorities in Warsaw occurs on two, seemingly separate, planes. The first one sees community leaders interacting with each other, but doing so on their own behalf, rather than as representatives of their respective communities. As the interactions follow a degree of structure and intended form, they result in certain measurable outcomes (for example, declarations and meetings). The second plane is much less structured-one could even characterise it as an anarchic space for spontaneous meetings. While Jewish-Muslim interactions take place on these two main planes, they sometimes overlap and influence each other, or even create a specific kind of synergy. Such was the case in September 2021, when the Community of Conscience issued a statement on the urgent need for action to support refugees staying on the Polish-Belarusian border: "Motivated by a sense of human solidarity, we call on the competent Polish authorities to immediately provide the refugees staying in the border area with the necessary humanitarian aid (... )" (Więź 2021). It is worth noting that the general conclusion that can be drawn from all the interviews is that the experience of belonging to 
a minority community makes people particularly sensitive and empathetic towards others, especially those who are somehow disadvantaged.

Finally, a common conclusion that can be drawn from the empirical study is that the Jews and Muslims living their lives in Poland's capital are rather careful, or even reluctant, to formulate sharp political opinions. This applies to both international affairs-including the Palestinian-Israeli conflict-and domestic, highly politicised disputes. This specific kind of caution can be explained as the fear of being instrumentalised, but also as a form of ambivalent feelings towards controversial issues, such as the Middle Eastern conflict. Such complex sentiments can be illustrated by a testimony of one Jewish interlocutor: "for some, this issue is black and white, for me it is not so simple. On the one hand, I would like the policy towards Palestine to be different. On the other hand, this conflict becomes unsolvable after so many years and it is not only Israel's fault" (Warsaw's interview partner number 2). Meanwhile, one of the interviewed Muslim community leaders emphasised: "we don't want to be part of politics and political games, we can cooperate with everyone but don't want to be on anybody's side, our role is work for the community" (Warsaw's interview partner number 4).

\section{Discussion}

At first glance, the exploration initiated by the Special Issue entitled "Are MuslimJewish Relations Improving in the 21st Century?", promised rather sceptical findings. In the popular imagination, sustained by mainstream media, but also according to selected academic studies (Jikeli 2015), Muslims and Jews rarely coexist in harmony. In parallel, a growing number of interesting projects encouraging dialogue and conviviality have been launched at the local level, but with global resonance.

The authors selected the qualitative anthropological methodology to employ an original perspective without overlooking the inherently problematic status quo. The choice allowed us to detect and explore newly emerging phenomena and trends, rather than limit the scope of the research with a strongly formulated hypothesis. The outcome of this fluid research approach proved to be highly rewarding, as several rather unexpected results surfaced from the final analysis.

The city of Berlin, as an eclectic capital hosting multi-ethnic diasporas, is an example of cultural hybridisation, as it consciously strives to re-create its pre-WWII ambiance of "Babylon-Berlin". The city of Dubai is a swiftly growing hub in the middle of the desert, with a population that grew by a factor of 12 over the last four decades. While Dubai builds its multicultural, tolerant image, it continues to honour its Islamic roots by recognising the centrality of religion and respecting the conservative regional context. This dichotomy is also its main challenge. Observers looking through a Eurocentric lens, struggle to reconcile the fact that Dubai stands as a synonym for a liberal environment within its Middle Eastern framework, but, at the same time, its Sharia law continues to provide, together with civil law, the guidelines for the country's judicial system.

Meanwhile, Warsaw is an exemplary city of Central-Eastern Europe-pulsating and alive with events, but not yet successful in renewing its pre-war atmosphere of the radical fusion between the East and the West. Since the early 1990s, Central European intellectual elites and artists have made vast efforts to initiate a Jewish renaissance by creating room in the public space for exhibiting Jewish culture and traditions. The process is aptly described in an insightful book, Virtually Jewish: Reinventing Jewish Culture in Europe (Gruber 2002). Along this line of thought, one should also consider old Muslim-Polish diasporas that provide a crucial background for the trends described here. Undeniably, populations of Central-Eastern European Jewish and Muslim minorities are considerably less numerous than in the West; at the same time, their role seems often disproportionally amplified in the imagination of majority societies. Moreover, Jewish and Muslim figures are often interchangeable, as illustrated by a relatively recent incident in a demonstration against accepting Muslim refugees in Poland, which escalated into the burning of an effigy of an ultra-Orthodox Jew holding the flag of the EU (I24news 2015). Conspiracy theories blaming 
Jews for the "Islamisation" of Europe by allegedly orchestrating the migration of Muslims have recently grown in popularity (Tarant 2016).

The hidden potential of such profoundly traumatising events lies in the strengthening of mutual solidarity among the groups in question-a trend that eventually manifests itself in publicly expressed support. However, in the particular case of Warsaw, the cultural and interfaith encounters of Jews and Muslims remain somewhat limited, and each minority is mainly dedicated to its own self-cultivation and striving. This landscape mirrors a relatively passive approach adopted by the local authorities.

Nevertheless, in each of these cities, research outcomes have shown that interactions between Jews and Muslims are, to various extents, acknowledged and, in some cases, also embody a formative part of public discourses. Perhaps, the most visible manifestations of these newly arising trends are ambitious interfaith projects that have recently been established in each geographical area in focus. The Abrahamic Family House, The House of One, and The Community of Conscience are revealing tireless aspirations of multi-faith religious leaders to overcome polarising dichotomies in search of common ground.

One of the least anticipated outcomes of the study is the realisation that the impact of the Israeli-Palestinian conflict on Jewish-Muslim relations in all three examined cities has been diminishing. Based on the authors' previous works (Menachem Zoufalá 2020; Dyduch 2019), these findings were partially expected in Central-Eastern European discourses. Much less so, however, in ultra-liberal Berlin or the prevalently Muslim Dubai. It is needless to emphasise that the conflict, painfully running through generations, was perceived by most of the interview partners as a great human tragedy for both sides. At the same time, its influence on the long-term efforts in the interfaith dialogue (or trialogue), intercultural and educational community building, or business initiatives, was considered rather marginal. These findings have even more significance, given the fieldwork's timing. All three field trips were carried out a few weeks, or even days (in the case of Dubai), after the war between Israel and Hamas, in May 2021. This unintended scheduling allowed the researchers to pay detailed attention to this highly sensitive and inflammable topic that can be easily politicised. As mentioned earlier, ethical considerations are the utmost priority of this study, and authors constantly questioned and challenged their own analysis, while evaluating these controversial, although authentic, results.

Perhaps, the most extraordinary phenomenon revealed by this study is an emerging potential for developing a joint Muslim-Jewish Middle Eastern identity. The West serves here as the "obligatory" counter-image for any distinct identity formation. The regional sense of belonging with a tinge of Occidentalism, identified in the Dubai case study, heavily draws on a narrative represented by the concept of Abrahamic cousins that is carefully cultivated by authorities on both sides. Nonetheless, to claim these findings are complete would certainly be a premature assertion. A follow-up long-term study is certainly encouraged to determine whether this Muslim-Jewish "\#Cousins Meetup identity" will represent an isolated occurrence, or may actually reach the mainstream environment.

Potential directions for future research, meant to improve our understanding of intercultural and interfaith relations in contemporary societies, can include a focus on Muslim-Christian, Jewish-Christian, or even triangular ties. Finally, it seems evident that inter-religious initiatives and cultural projects, as it was described in the case of Dubai, Berlin, and Warsaw, can also serve as successful civil forces-in Western as well as Arab countries-for combating prejudice and reservations, preventing parallel societies, or even reducing group-related enmity.

Author Contributions: Conceptualization, M.M.Z., J.D. and O.G.; methodology, M.M.Z.; software, not applicable; validation, M.M.Z., J.D. and O.G.; formal analysis, M.M.Z., J.D. and O.G.; investigation, M.M.Z., J.D. and O.G.; resources, M.M.Z., J.D. and O.G.; data curation, M.M.Z., J.D. and O.G.; writingoriginal draft preparation, M.M.Z., J.D. and O.G.; writing_review and editing, M.M.Z., J.D. and O.G.; visualization, M.M.Z., J.D. and O.G.; supervision, M.M.Z., J.D. and O.G.; project administration, M.M.Z., J.D. and O.G.; funding acquisition, M.M.Z. and O.G. All authors have read and agreed to the published version of the manuscript. 
Funding: This article was supported by the grant UDISEJ-Erasmus+ 2018-1-CZ01-KA203-048165'United in Diversity' - An Interdisciplinary Study of Contemporary European Jewry and Its Reflection.

Institutional Review Board Statement: The study was conducted according to the guidelines of the Declaration of Helsinki. Further, the authors declare that research fully complies with the Statement on Ethics: Principles of Professional Responsibility issued by the American Anthropological Association (AAA) in 2012: https: / / www.americananthro.org/LearnAndTeach/Content.aspx?ItemNumber= 22869 (accessed on 2 September 2021). Please note there is no Institutional Review Board (or Ethics Committee) at Institute of the Middle and Far East, Jagiellonian University and Moses Mendelssohn Centre for European Jewish Studies, University of Potsdam.

Informed Consent Statement: Informed consent was obtained from all subjects involved in the study.

Data Availability Statement: The data presented in this study are partially available on request from the corresponding author. The data are not publicly available due to respondents' privacy protection, emotional security and general ethical considerations.

Conflicts of Interest: The authors declare no conflict of interest.

\section{Notes}

1 The first steps and the coordination of the initiative have been undertaken by dr Sebastian Rejak, acting director of the American Jewish Committee Central Europe, based in Warsaw.

2 The research questions and the questionnaire that was in use for the anthropological fieldwork in Dubai, Berlin, and Warsaw are based on a project "United in Diversity"-An Interdisciplinary Study of Contemporary European Jewry and Its Reflection, which was awarded a multiyear grant under the Erasmus+ program, Key Action 2: Strategic Partnerships, by The Czech National Agency acting under delegation of the Education, Audiovisual, and Culture Executive Agency (EACEA) of the EU. The project is carried out by Charles University, as a coordinating institution, The Moses Mendelssohn Center for European Jewish studies at the University of Potsdam, Comenius University, and Tel Aviv University. The main research topic is to study crucial questions of contemporary Jewish life, focusing on the nature of relations between Jews and non-Jews in Germany, Czechia, Slovakia, Poland, and Hungary. The present paper rests on the findings of the previous, yet unpublished, study.

3 The case study of Dubai was carried out by Marcela Menachem Zoufalá, the case study of Berlin by Olaf Glöckner, and the case study of Warsaw by Joanna Dyduch.

4 The primary intention was to contact key figures from both sides (purposive sampling), followed by exponential non-discriminative snowball sampling.

5 Challenging social desirability bias is one of the major obstacles faced by the researchers. Many techniques (e.g., strictly neutral way of questioning, unbiased, carefully selected wording, researcher's openness and honest introspection) can prevent a large portion of desirability bias from interfering with the final analyses and meaningfully changing the course of accounts.

6 The term of theoretical saturation was initially coined in the renowned grounded theory (Glaser and Strauss 1967). In qualitative methodology, saturation commonly represents a criterion to determine whether the research was sufficiently supplied (saturated) with data, and it is possible to cease gathering information and analyses. There is a widespread consent, aptly captured e.g., by Given, that saturation is the point at which "additional data do not lead to any new emergent themes" (Given 2016, p. 135).

Interview partner number 1 .

8 According to the postulates of the reflexive methodology, authors of this study prefer to address the specific interviewees as "interview partners", rather than "respondents", to emphasize their active role and significant contribution to the research. Taking into account several ethical considerations which differed for each research location, it was judged that keeping parts of the accounts anonymised would be more sensitive. However, in Berlin our interview partners were exceedingly open-minded about being quoted by full name, especially in the context of their own projects on Muslim-Jewish cooperation.

9 The Jews of Dubai are on the map, 2019, https:/ / www.ynetnews.com/articles/0,7340,L-5458305,00.html (accessed on 2 September 2021). Shul is a Yiddish term for synagogue.

UAE-figures: Religions: Muslim (official) 76\%, Christian 9\%, other (primarily Hindu and Buddhist, less than 5\% of the population consists of Parsi, Baha'i, Druze, Sikh, Ahmadi, Ismaili, Dawoodi Bohra Muslim, and Jewish) 15\% (2005 est.); Ethnic groups: Emirati 11.6\%, South Asian 59.4\% (includes Indian 38.2\%, Bangladeshi 9.5\%, Pakistani 9.4\%, other 2.3\%), Egyptian 10.2\%, Filipino 6.1\%, other $12.8 \%$ (2015 est.) https:/ / www.cia.gov/the-world-factbook/countries/united-arab-emirates/ (accessed on 2 September 2021).

12 United Arab Emirates Population Statistics 2021, Posted 1 July 2021, https:/ / www.globalmediainsight.com/blog/uae-populationstatistics/ (accessed on 2 September 2021). 
This is not a unique case, as a few interview partners mentioned having several Emiratis friends learning or even speaking fluent Hebrew. Considering the fact that in both countries overwhelming majority speak English, this could be rather seen as an expression of deeper interest than a pure communication tool.

The interview partners' selection is unfortunately not gender-balanced. There was only one female interview partner in the whole group. This issue is considered highly problematic and will receive the deserved focus in the follow-up research. Interview partner number 2 .

Interview partner number 3.

It is pointless to emphasize that Abraham accords, in general, are sometimes portrayed as a merely pragmatic reaction to the commonly perceived threat represented by Iran. Whether the discussed interfaith efforts are of diplomatic nature or rather an authentic sign of mutually developing attitudes will for now remain unanswered.

Considering that the assailant Kobili Traoré, Muslim of Malian origin, shouted Allahu akbar during the attack and afterward proclaimed, "I killed the Shaitan," it is a shocking fact that the French government was for several months reluctant to acknowledge the antisemitic nature of the killing. Eventually, Traoré was declared insane and therefore not criminally responsible due to long-term cannabis consumption. (BBC 2021). Interview partner number 4 .

The slogan of "Cousins Meetup" was used, for example, to capture the atmosphere of the trip of young Israeli influencers to Dubai, where they met their Emiratis counterparts. In the lexicon of Israeli Jews, the word "cousins" often represents Arabs. The trip was organized by Israel-is in coordination with the Israeli Strategic Affairs Ministry and sanctioned by the Emirati government. https:/ / www.jpost.com/middle-east/cousins-meetup-bringing-young-israelis-emiratis-together-664605 (accessed on 22 December 2021).

Statistical Populations Report of the City of Berlin, 30 June 2019, especially page 17. https://download.statistik-berlinbrandenburg.de/b4aeb23c1313184d/27c6b0c93f0a/SB_A01-05-00_2019h01_BE.pdf (accessed on 9 October 2021). Most Berliners with an Arab migration background come from Syria (43,304 people), followed by Lebanon (29,561 people). According to Amt für Statistik Berlin-Brandenburg, 30 June 2019. See also: https:/ / russkij.berlin/ (accessed on 9 October 2021). Holocaust Encyclopedia. https:/ / encyclopedia.ushmm.org/content/en/article/germany-jewish-population-in-1933 (accessed on 3 October 2021)

A global survey of the Anti Defamation League in 2014, followed up by surveys in 2015, 2017 and 2019, revealed that more than $70 \%$ of the Middle East population had significant Antisemitic attitudes. https:/ / global100.adl.org/map (accessed on 3 October 2021). Understandably, some Jewish representatives expressed their fear that enmity against Jews in Germany could increase. According to previous statistics, Antisemitic crimes in Germany were mainly carried out by right-wing extremists. Alongside other voices, some scholars have postulated a new, more nuanced system of recording Antisemitic hate crimes. The idea is currently discussed by a commission in the Germany Ministry of the Interior. It is assumed that a significant portion of hate crimes are committed by other groups (not only by far-right fanatics), including Muslims and far left extremists. The assumption is supported by the results of FRA surveys conducted in 2013 and 2017 among Jews in several EU member states. The FRA studies provide an important piece to the overall picture of individual Jewish experiences with Antisemitic hate crimes in contemporary Europe. Interview with Osman Örs (Berlin) on 4 June 2021, by Zoom.

Interview with Kübra Dalkilic on 4 July 2021, in Berlin (personal meeting). Interview with Seda Kolac on 6 July 2021, in Berlin (personal meeting). Interview with Seda Kolac on 6 July 2021, in Berlin (personal meeting). Interview with Kübra Dalkilic on 4 July 2021, in Berlin (personal meeting). Interview with Ruth Fischer on 10 July 2021. Interview with Susanne Krause-Hinrichs, 8 July 2021, in Potsdam. Interview with Kadir Sanci, 3 July 2021, by Zoom. Interview with Seda Kolac on 6 July, in Berlin (personal meeting). https:/ / shalom-rollberg.de/ (accessed on 7 July 2021) Interview with Yonatan Weizman in Berlin, 9 July 2021. Interview with Yonatan Weizman in Berlin, 9 July 2021. Regarding the initiative "Salaam-Schalom" see: (Heins 2020).

The Muslim League in the Republic of Poland was established on 14 April 2001 on the initiative of Polish Muslims in response to the growing number of Muslims in Poland and due to the great needs of the Muslim community. The League was officially registered on 6 January 2004 at the Department for Religious Denominations, National and Ethnic Minorities at the Ministry of the Interior and Administration and officially entered into the Register of Churches and other religious associations. 
Nevertheless, it is worth noting that there is a long lasting, fruitful and quite well visible in the urbane space cooperation between Muslims and Jews in few other Polish cities as for instance Katowice or Poznan. Annual initiatives as joint publication of Calendar of three Religions: Jews, Christians and Muslims or a joint organisation of Days of Judaism and Christianity in Muslims community and vice versa, may serve as a representative examples.

40 Among those 12 there were key representatives of Warsaw's Jewish and Muslim communities: Imam Rafał Berger (Common Council of Catholics and Muslims, Co-President from the Muslim side), Rabinka Małgorzata Kordowicz (Jewish Community of Warsaw), Prof. Stanisław Krajewski (Polish Council of Christians and Jews, Jewish Co-Chair), Mufti Tomasz Miśkiewicz (Muslim Mufti in the Republic of Poland), Dr Sebastian Rejak (Acting Director, AJC Central Europe), Rabin Michael Schudrich (Chief Rabbi of the Republic of Poland).

41 Mission Statement https://wspolnotasumienia.pl/mission-statement-en.pdf (accessed on 30 August 2021).

42 The Danube Institute for Dialogue is a non-profit organization with the primary aim of contributing to building bridges between communities, promoting cooperation, partnership and service to society through intercultural dialogue and discussion. The Danube Institute for Dialogue operating in Warsaw (Poland) serves as an umbrella for Hizmet Movement (known also as a Gülen's Movement) operation. https://www.dialoginstytut.pl/o-fundacji/ruch-hizmet/ (accessed on 30 August 2021).

\section{References}

AJC. 2020. Available online: https://www.ajc.org/news/muslim-world-league-secretary-general-dr-al-issa-addresses-ajc-globalforum (accessed on 28 October 2021).

Atshan, Sa'ed, and Katharina Galor. 2020. The Moral Triangle: Germans, Israelis, Palestinians. Durham: Duke University Press.

Ayoub, Phillip M. 2016. When States Come Out: Europe's Sexual Minorities and the Politics of Visibility. Cambridge: Cambridge University Press.

BBC. 2021. Available online: https:/ /www.bbc.com/news/world-europe-56929040 (accessed on 30 November 2021).

Bertram, Łukasz, Adam Puchejda, and Karolina Wigura. 2017. Negatywny Obraz Muzułmanów w Polskiej Prasie Analiza Wybranych Przykładów z lat 2015-2016. Raport Obserwatorium Debaty Publicznej “Kultury Liberalnej”, Warszawa, Styczeń 2017 r. Available online: https://bip.brpo.gov.pl/sites/default/files/Raport_Negatywny_obraz_muzulmanow_w_polskiej_prasie_Analiza_ wybranych_przykladow_z_lat_2015_2016.pdf (accessed on 30 August 2021).

Bobako, Monika. 2017. Żyd i Arab/muzulmanin w europejskich geometriach tożsamości i różnicy. [Jew and Arab/Muslim in European Geometries of Identity and Difference]. Warszawa: The Institute of Literary Research of the Polish Academy of Sciences, No.2. pp. 255-79. [CrossRef]

CBOS. 2019. Postawy Wobec Islamu i Muzułmanów [Attitude Towards Islam and Muslims]. Nr 148/2019. Grudzień: Centrum Badania Opinii Społecznej, Available online: https:/ /www.cbos.pl/SPISKOM.POL/2019/K_148_19.PDF (accessed on 30 August 2021).

Czerwińska-Jędrusiak, Barbara. 2009. Ludność $i$ Powierzchnia Warszawy w Latach 1921-2008. [Population and area of Warsaw in the years 1921-2008]. Warszawa: Urząd Statystyczny.

Dobroszycki, Lucjan. 1973. Restoring Jewish life in post-war Poland. Soviet Jewish Affairs 3: 58-72. [CrossRef]

Dyduch, Joanna. 2019. Die Visegrád-Staaten und Israel Dimensionen und Funktionen einer Sonderbeziehung. Osteuropa 69: 351-67.

Engel, David. 2015. The End of a Jewish Metropolis? The Ambivalence of Reconstruction in the Aftermath of the Holocaust. In Dynner, Warsaw. The Jewish Metropolis. Essays in Honor of the 75th Birthday of Professor Antony Polonsky, IJS Studies in Judaica. Edited by Glenn and Guesnet François. Leiden: Brill, vol. 15, pp. 562-69. [CrossRef]

Euronews. 2021. Available online: https:/ /www.euronews.com/2021/04/25/sarah-halimi-thousands-protest-decision-not-to-tryjewish-woman-s-killer (accessed on 3 October 2021).

Everett, Samuel Sami, and Ben Gidley. 2018. Getting away from the Noise: Jewish-Muslim Interactions and Narratives in E1/Barbès. Francosphères. Available online: https:/ / archive.jpr.org.uk/10.3828/franc.2018.13 (accessed on 2 September 2021).

Gallagher, Carolyn, Carl T. Dahlman, Mary Gilmartin, Alison Mountz, and Peter Shirlow. 2009. Key Concepts in Political Geography. Key Concepts in Human Geography. London: SAGE Publications.

Given, Lisa M. 2016. 100 Questions (and Answers) about Qualitative Research. Thousand Oaks: Sage.

Glaser, Barney G., and Anselm L. Strauss. 1967. The Discovery of Grounded Theory: Strategies for Qualitative Research. Chicago: Aldine.

Górak-Sosnowska, Katarzyna, ed. 2011. Muslims, in Poland and Eastern Europe Widening the European Discourse on Islam. Warszawa: University of Warsaw, Faculty of Oriental Studies.

Gruber, Ruth Ellen. 2002. Virtually Jewish: Reinventing Jewish Culture in Europe. Berkeley and Los Angeles: University of California Press.

Gubrium, Jaber F., and James A. Holstein. 2009. Narrative Ethnography. In Handbook of Emergent Methods. Edited by Sharlene N. Hesse-Biber and Patricia Leavy. New York: Guilford Press.

GUS. 2018. 100 lat Polski w Liczbach. 1918-2018 [100 Years of Poland in Numbers. 1918-2018]; Warszawa: Główny Urząd Statystyczny, Departament Opracowań Statystycznych. Available online: https://stat.gov.pl/download/gfx/portalinformacyjny/pl/ defaultaktualnosci/5501/30/1/1/100_lat_polski_w_liczbach_1918-2018.pdf (accessed on 14 August 2021).

GUS. 2019. Religious Denominations in Poland 2015-2018; Statistical Analyses. Warsaw: Główny Urząd Statystyczny/Statistics Poland. Available online: https://stat.gov.pl/obszary-tematyczne/inne-opracowania/wyznania-religijne/wyznania-religijne-w-polsce20152018,5,2.html\# (accessed on 14 August 2021). 
Hegel, Georg Wilhelm Friedrich. 2007. Philosophy of Mind: Translated with Introduction and Commentary by Michael Inwood. Oxford: Oxford University Press.

Heins, Volker M. 2020. The Righteous of the Transnation. Jews, Muslims and a Politics of Friendship in Berlin. In The Courage for Civil Repair. Edited by Carlo Tognato, Bernadette Nadya Jaworsky and Jeffrey C. Alexander. Berlin: Springer, pp. 35-60. Available online: https:/ /link.springer.com/chapter/10.1007\%2F978-3-030-44590-4_2 (accessed on 2 September 2021).

I24news. 2015. Protesters Burn Effigy of Orthodox Jew at Anti-Immigration Protest in Poland. Available online: https://www.i2 4news.tv/en/news/international/europe/93019-151120-protesters-burn-effigy-of-orthodox-jew-at-anti-immigration-protestin-poland (accessed on 2 September 2021).

Jansen, Yolande. 2020. 'A crooked, passion-laden mirror': 'Jews' and 'Muslims'as a European question beyond religio-secularism. Patterns of Prejudice 54: 29-45. [CrossRef]

Jikeli, Günther. 2015. European Muslim Antisemitism: Why Young Urban Males Say They Don't Like Jews. (Studies in Antisemitism). Bloomington: Indiana University Press.

Jikeli, Gunther. 2020. Assessing the Threat of Antisemitic Harassment and Attack in France-Paris in Focus. Journal of Contemporary Antisemitism 3: 71-82. [CrossRef]

Krajewski, Stanisław. 2005. Poland and the Jews: Reflections of a Polish Polish Jew. Kraków: Austeria.

Leerssen, Joep. 2018. Imagology: On Using Ethnicity to Make Sense of the World. Porównania 21: 9-30. [CrossRef]

Lev Ari, Lilach. 2022. Contemporary Jewish Communities in Three European Cities: Challenges of Integration, Acculturation and Ethnic Identity. Berlin: De Gruyter.

Menachem Zoufalá, Marcela. 2020. Ethno-Religious Othering as a reason behind the Central European Jewish distancing from Israel. In Being Jewish in 21st Century Central Europe. Edited by Haim Fireberg, Olaf Glöckner and Marcela Menachem Zoufalá. Series: Europäisch-jüdische Studien; Berlin: De Gruyter, ISBN-13: 978-3110579659.

Narkowicz, Kasia, and Konrad Pędziwiatr. 2017. From unproblematic to contentious: Mosques in Poland. Journal of Ethnic and Migration Studies 43: 441-57. [CrossRef]

Pew Research Center. 2019. European Public Opinion Three Decades after the Fall of Communism. REPORT 2019. pp. 80-85. Available online: https://www.pewresearch.org/global/wp-content/uploads/sites/2/2019/10/Pew-Research-Center-Valueof-Europe-report-FINAL-UPDATED.pdf (accessed on 2 September 2021).

Renton, James, and Ben Gidley, eds. 2017. Antisemitism and Islamophobia in Europe: A Shared Story? London: Palgrave Macmillan.

Robertson, Roland. 1992. Globalization. Social Theory and Global Culture. London: SAGE Public. Ltd.

RPO. 2016. O Sytuacji Polskich Muzułmanów i Muzułmanów w Rzeczypospolitej na Spotkaniu Adama Bodnara w Biurze RPO. June 21. Available online: https://bip.brpo.gov.pl/pl/content/o-sytuacji-polskich-muzulmanow-i-muzulmanow-w-rzeczypospolitejna-spotkaniu-adama-bodnara (accessed on 21 August 2021).

Skowron-Nalborczyk, Agata. 2016. Relations between the State and Islam in Finland and Poland. In Muslim Minority-State Relations. The Modern Muslim World. Edited by Robert Mason. New York: Palgrave Macmillan. [CrossRef]

Skowron-Nalborczyk, Agata. 2020. Poland. In Yearbook of Muslims in Europe. Edited by Oliver Scharbrodt, Samim Akgönül, Ahmet Alibašić, Jørgen S. Nielsen and Egdūnas Račiūs. Leiden: Brill, pp. 488-504.

Switat, Mustafa. 2017. Społeczność Arabska w Polsce. Stara i Nowa Diaspora. [Arab Community in Poland. Old and New Diaspora]. Warszawa: Dialog.

Tarant, Zbyněk. 2016. “Antisemitism in Response to the 2015 Refugee Wave-Case of the Czech Republic" 28 January 2016Flashpoint 13. Available online: https:/ / isgap.org/flashpoint/antisemitism-in-response-to-the-2015-refugee-wave-the-case-of-the-czechrepublic/ (accessed on 2 September 2021).

The UAE-Israel Business Council (UIBC). 2021. Abraham Accords Anniversary Brochure. Tel Aviv: The UAE-Israel Business Council (UIBC), Available online: https://www.uaeisraelbusiness.com/wp-content/uploads/2021/08/Brochure-UIBC-2021-23.pdf (accessed on 2 September 2021).

Wagner, Katarzyna, Krzysztof Zwierz, and Przemysław Piechocki. 2016. Ską się Biora Warszawiacy? Migracje do Warszawy w XIV-XXI Wieku. [Where are the Varsovians coming from? Migrations to Warsaw in the 14th-21st centuries]. Warszawa: Muzeum Warszawy.

Więź. 2021. Nie Możemy Patrzeć na Cierpienie Uchodźców Jedynie ze Smutkiem i Bezsilnością". Oświadczenie Wspólnoty Sumienia. 30 Sierpnia 2021. Available online: https:/ / wiez.pl/2021/08/30/nie-mozemy-patrzec-na-cierpienie-uchodzcow-jedynie-zesmutkiem-i-bezsilnoscia-oswiadczenie-wspolnoty-sumienia/ (accessed on 12 August 2021).

Wyborcza.pl. 2010. Żydzi sa za Zbudowaniem Meczetu w Warszawie. List do Redakcji [Jews Are in Favor of Building a Mosque in Warsaw. A Letter to the Editors]. Warszawa: Wyborcza, March 30. 